\title{
Current Situation Analysis and Strategy Exploration of Ocean English Learning in Primary and Secondary Schools in Zhoushan
}

\author{
Ye Qiongna ${ }^{1}$, Jiadai MAO ${ }^{2}$ \\ ${ }^{I}$ College of Foreign Languages, Zhejiang Ocean University, Zhejiang \\ ${ }^{2}$ College of Foreign Languages Zhejiang Ocean University
}

*Corresponding Author: Ye Qiongna, College of Foreign Languages, Zhejiang Ocean University, Zhejiang, China

\begin{abstract}
The teaching of Ocean English refers to the integration of oceanic culture and English language teaching in the teaching process. At present, the teaching of Ocean English in Zhoushan'sprimary and secondary schools still excist problems. For example, the teaching policy implementation is not complete, the use of textbooks is insufficient, and even students become less interested in English learning. This essay, by means of survey and research, has come up with a serious of steps, hope to provide reference for Ocean English teaching in primary and secondary schools in Zhoushan.
\end{abstract}

Keywords: Zhoushan City; English for Primary and Secondary Schools; Ocean English; English Learning; Current Situation Analysis; Strategy Exploration

\section{BACKGROUND}

In 2016, Zhoushan Aarchipelago New Area was approved by the state council to set up The China (Zhejiang) Pilot Free Trade Zone, which is a development opportunity for Zhoushan ${ }^{[1]}$. Therefore, The idea "Open up to the world and connect with the society "becomes an innevitable tendency in Zhoushan's current mode of development ${ }^{[2]}$. Under an increasingly international new situation, as an international language, English has an important impact on Zhoushan 's external exchanges. Among them, the promotion of the Ocean English which brought together marine folk customs, regional culture, traditional diet and so on plays an important role in the publicity of Zhoushan 's special marine culture and international image of island ${ }^{[3]}$. So, nowadays, cultivating English learning awareness of the public will be helpful to move forward and diffuse the Ocean English. Hence, It is a pivotal point that students in Zhoushan 's primary and secondary schools should pay attention to the Ocean English learning enriching and accumulating enough ocean awareness and improving the oral English communicative competence. However, this paper did a preliminary investigation and analysis of the Ocean English learning in Zhoushan 's primary and secondary schools, the survey shows that the Ocean English teaching policy implementation is not complete, and a little work was done on that.At the same time, the teaching materials are not good, and the teaching mode is lack of innovation. What's more, from the students' points of view, their interest in Ocean English is at a low and real-life ability of commanding and applying performed poorly. Considering the above analysis, at present, the task of teaching Ocean English in Zhoushan's primary and secondary schools is still far from perfect.

\section{THE OCEAN ENGLISH}

Marin culture is ocean-related culture and originates from ocean. It is the meaning of mental, behavioral social and material civilized life created in human understanding, grasping, developing and utilizing ocean and adjusting relationships between human and ocean[4]. Chinese marine culture is divided into marine folk customs, marine humanistic landscape,marine culture industry, marine food culture and so on.

Ocean English, which fuses the marine culture with marine native features, uses English communication as its carrier, was a language with unique local flavor[5]. The Ocean English teaching needs teachers to lay emphasis on the introduction and infiltration of marine culture aspect during the teaching process. Through teaching and learning, finally, students will understand and grasp the Ocean English based on the basic English learning, developed their personal knowledge-bank about 
marine culture, promote their daily Ocean English communicating skill.

\section{THE RESEARCH STATUS ABOUT OCEAN ENGLISH}

After a preliminary investigation, this research found that the current teaching teaching status of Ocean English in Zhoushan's primary and secondary schools was not ideal. There are some serious problems in schools, teachers and students. The survey showed that in Zhoushan, $75 \%$ of the primary and secondary schools didn't set up this course, and the hour distribution about the course is short. In the mean time, when asked how well they know about the Ocean English, $61 \%$ barely understand that, and 34\% showed that they just have a basic understanding, and only 5\% of the people have a deep understanding and mastery. From the above datum, to date, the teaching of Ocean English was particularly disadvantaged, and most people's consciousnesses aren't strong, and not enough attention about Ocean English was paid to the training.

\section{EMPIRICAL STUDY}

\subsection{The Object of Study}

- The questionnaire survey was mainly targeted at the primary and secondary school students in Zhoushan. A total of 480 questionnaires were distributed, and 480 questionnaires were returned and 400 valid questionnaires. Questionnaires were evenly distributed among students in grade one to twelve.Among the students surveyed, one fourth of the students were middle school students in PuTuo District, and the proportion of the Ocean English occupied in learning was relatively high.

- The interviewees in this study were related English teachers and teaching staff in all grades of primary and secondary schools in Zhoushan. Compared with teachers in primary schools, English teachers in middle schools had a greater degree of understanding of Ocean English.

- This study also developed a classroom record observation table, mainly for the performance of teachers and students in the primary and secondary school English teaching classes in Zhoushan City.

\subsection{Survey Tool}

\subsubsection{Survey Questionnaire}

The questionnaire was designed in Chinese and used an anonymous form ${ }^{[6]}$. The target of the questionnaire is mainly the student group. The questionnaire mainly includes the following points:

- The level of interest in learning the Ocean English

- The frequency of exposure to the Ocean English and the degree of understanding

- The actual application of Ocean English in daily life

\subsubsection{Interview Questions}

The interview were composed of semi-guided and guided questions. This survey firstly asked the English teachers and senate members about their understandings of Ocean English, based on this, follow-up interviews would be conducted. The main interview questions include the following points:

- Teaching mode of Ocean English courses and problems in teaching process

- Attitudes towards the establishment of Ocean English-related courses

- The use of teaching materials in the teaching process

- Whether or not the knowledge allocation and teaching feedback of computer English related courses in school units are in place

\subsection{Analysis of Survey Results}

\subsubsection{Problems in Schools and Analysis:(See Table One)}

- Findings in Zhoushan showed that $75 \%$ of the schools had no courses about Ocean English, only $25 \%$ had these courses. So we can see from these two numbers, primary and secondary 
school students in Zhoushan had low regard for Ocean English, and the Ocean English was not widely spread.

- Ocean English courses were allocated less in class, according to the survey, in the schools which offer courses about Ocean English, 80 percent of these schools arrange the courses twice a week, and one lesson is 45 minutes, but the rest 20 percent of these schools arranged the course once a week.

- The teaching feedback of Ocean English course was not in place. 85\% of schools did not have a systematic and comprehensive approach to teaching evaluation.

Table1

\begin{tabular}{|c|c|c|}
\hline Questions & Choice Items & Feedback Situations \\
\hline $\begin{array}{c}\text { The importance ofOcean } \\
\text { English }\end{array}$ & $\begin{array}{l}\text { Having set up the Ocean English } \\
\text { course } \\
\text { No Ocean English course is offered }\end{array}$ & $\begin{array}{l}25 \% \\
75 \%\end{array}$ \\
\hline Curriculum allocation & $\begin{array}{c}\text { Every two weeks } \\
\text { Every week }\end{array}$ & $\begin{array}{l}80 \% \\
20 \%\end{array}$ \\
\hline $\begin{array}{l}\text { The implementation of } \\
\text { feedback work }\end{array}$ & $\begin{array}{c}\text { Making a systematic and } \\
\text { comprehensive teaching evaluation } \\
\text { method } \\
\text { No systematic and comprehensive } \\
\text { teaching evaluation method }\end{array}$ & $85 \%$ \\
\hline
\end{tabular}

\subsubsection{Problems and Analysis in Teachers' Group}

- The teachers' understanding and mastery of Ocean English professional knowledge was not satisfactory. After investigation, $85 \%$ of primary and middle school teachers did not have rich vocabulary of Ocean English, and the understanding of some marine cultures with local characteristics was also relatively weak.(see table two)

Table2

\begin{tabular}{|c|c|c|}
\hline Questions & Choice Items & Feedback Situations \\
\hline The degree of mastery of & Completely unknow & $15 \%$ \\
Ocean English Vocabulary & Be able to say some & $65 \%$ \\
& simple words & $20 \%$ \\
& $\begin{array}{c}\text { Understand some complex } \\
\text { professional vocabulary }\end{array}$ & 20 \\
\hline
\end{tabular}

- Ocean English teaching content in the classroom accounted for a small proportion. Surveys have shown that the form of high school was relatively severe. $80 \%$ of high schools pay attention to exam-oriented education, which results in a disadvantageous situation in teaching content unrelated to the college entrance examination. So in the classroom, teachers did not pay enough attention to the teaching of the Ocean English.

\begin{tabular}{|c|c|c|}
\hline Questions & Choice Items & Feedback Situations \\
\hline The main content of & Exam oriented education English & $80 \%$ \\
English learning & Ocean English related content & $20 \%$ \\
\hline
\end{tabular}

- The teaching style of the teachers is too traditional. Surveys showed that $80 \%$ of teachers focused on the "instruction-acceptance" teaching model in the development of teaching activities. They mainly focused on the instillation of textbook knowledge and incorporated some extracurricular marine vocabulary recognition. Supplementary work led to students' learning activities was too mechanized and passive.

- The use of textbooks is not high. 75 percent of secondary school teachers in Putuo District reported that due to the constraints of class hours and the control of class progress, although the contents of the textbooks are lively and interesting, they can only select a suitable portion for teaching, so the use of textbooks is not very satisfactory. 


\subsubsection{Problems in Student Groups}

- Students' interest in learning Ocean English was not high: $65 \%$ of students believed that current computer courses were lively and interesting. The vast majority of students in this section were primary school students from grades 1 to 6 , and $35 \%$ of students thought that Ocean English is plain but effective. Most of the students in this section were concentrated in junior high school, and even 10\% of students believed hat English classes were uninteresting and inefficient.(see figure one)
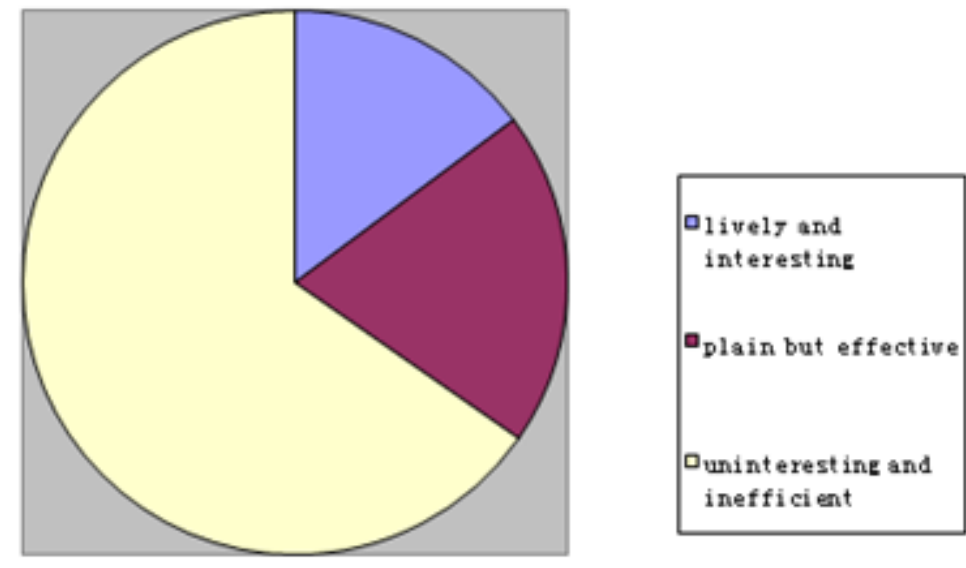

Figure1

- The frequency of student's exposure to Ocean English is not high and the degree of understanding of Ocean English is not deep. $60 \%$ of students have almost no exposure to Ocean English, and 33\% of students reported that they would come into contact with Ocean English every week, and 34\% of students were able to speak simple English words about Ocean English ,these mainly concentrated in junior high school.(see table four)

Table4

\begin{tabular}{|c|c|c|}
\hline Questions & Choice Items & Feedback Situations \\
\hline The frequency of students' & Hardly & $65 \%$ \\
exposure to computer English & Every semester & $33 \%$ \\
& Every English class & $2 \%$ \\
\hline The degree of understanding of & Fully understand & $66 \%$ \\
Ocean English & Almost underatand & $34 \%$ \\
\hline
\end{tabular}

- The practical application of Ocean English in the daily lives of students is not high. Only 20\% of students have a particularly positive attitude toward English daily communication. In addition, about $80 \%$ of students are resistant to the use of Ocean English in their daily lives, and they have few opportunities to use a single English language in their lives. They do not want to speak or speak English.(see figure two)
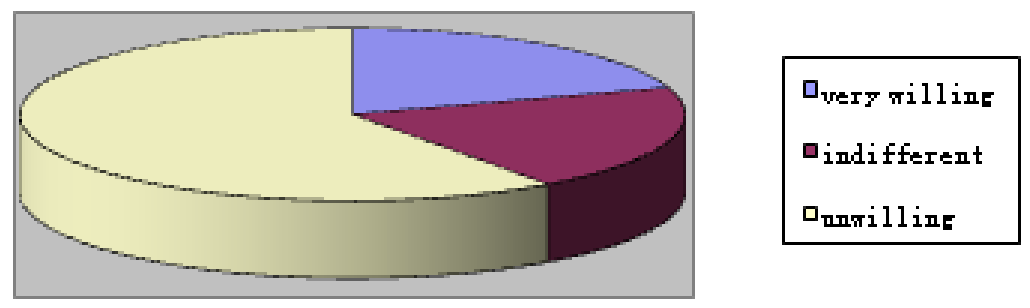

Figure2

\subsection{Research Strategy}

\subsubsection{Strategies for Schools}

- Actively develop and build English learning websites with the theme of "ocean". The school can set up an online learning platform for the special language of the door. The platform is for 
teachers, students, and parents. Online learning helps teachers make full use of network resources to open up a Ocean English learning campus, and students and parents can use the online platform to deepen their understanding of Ocean English. Students complete relevant exercises by watching Ocean English teaching videos on the learning platform, and they can again learn to consolidate the new knowledge in the classroom. At the same time, parents can also $\log$ in to the website to learn and broaden their English knowledge in the ocean field by learning with their children.

- Guarantee the full release of the learning policy. In early 2012, Putuo District launched a special project for the teaching of spoken English in the ocean. Since September of the same year, 《Putuo Ocean English Reader 》 has been used as a teaching material, and the local English course has been opened in the eighth grade of the district. Putuo District School has brought a good start. All primary and secondary schools in Zhoushan City should take action and recognize the language of Ocean English. According to the curriculum plan, the school should formulate curriculum plans and mobilizes teachers and students. The importance of Ocean English should be emphasized to students, teachers and even the entire development of Zhoushan. The thinking of teachers and students needs to be highly focused on this issue. At the same time, in the semester teaching process, schools should increase the frequency of teacher conferences and give teachers the opportunity to communicate with each other.

- Formulate a reasonable teaching evaluation method and conduct a teaching evaluation at the end of each semester. Teaching evaluation is an important part of teaching activities and an indispensable means and method for scientifically guiding teaching work ${ }^{[7]}$. As an administrative department of education, the school shall formulate a reasonable evaluation method for teaching. The final evaluation of the course can be conducted through various aspects such as the students' actual ability to grasp, the final grades finalized, the teacher's classroom performance, and parents' feedback. Having a reasonable inspection method is conducive to stimulating teachers' enthusiasm and providing favorable conditions for the follow-up of Ocean English teaching activities.

\subsubsection{Strategies for Teachers}

- Strengthen teachers' learning and mastery of Ocean English. The understanding of the concepts, uniqueness, and benefits of the English language by the English teachers in primary and secondary schools all have deficiencies and deviations. Strengthening the study and mastery of Ocean English is a condition for effective implementation of the Ocean English teaching policy. Therefore, the education administrative department should arrange systematically Ocean English theory learning and training for Zhoushan City Primary and secondary school teachers .Such learning and training should be held periodically, and the training content should cover the origin, development and related research of marine culture at home and abroad. At the same time, teachers are encouraged to review the literature on marine English for theoretical study.

- Strengthen teachers' multimedia operation skills. The school should regularly conduct systematic multimedia operation training to develop the teachers' ability to operate in the areas of teaching resources development, teaching multimedia applications, and online platforms. The training content is aimed at teachers' teaching work. After the teachers learn to actively use the actual combat, instead that the new Knowledge is shelved.

- Strengthen teachers' ability to teach. The education administrative department carries out training, teaching and research activities, etc., and conducts appraisal of different school teachers, and systematically strengthens the teacher's Ocean English class teaching methods.

\subsubsection{Strategies for Students}

- Raise the learning interest of primary and middle school students in Ocean English. Interest is the source of learning ${ }^{[8]}$. Therefore, to improve the current status of Ocean English learning for students in primary and secondary schools in Zhoushan, the first thing that needs to be improved is students' interest in learning Ocean English. The education administration 
department can draw students' attention by printing interesting Ocean English textbooks. In class, teachers can use multimedia devices such as ppt to deepen students' understanding of the concept of Ocean English, promote classroom atmosphere, and pay attention to students' practical application skills. Being able to use science to study and use, learning interest naturally rises.

- Cultivate students' autonomous learning ability. Autonomous learning ability is a manifestation of students' self-consciousness and autonomy. Students can actively learn relevant materials without supervision, complete their learning tasks independently, and develop independent thinking and problem solving skills ${ }^{[9]}$. Teachers play a supporting role in helping students to outline their study syllabuses and students complete the learning task list.

- Cultivate students' ability to collaborate in learning. One of the learning methods we use more often in classroom teaching is group learning ${ }^{[10]}$. Teachers in the class can set a suitable period of time to give students opportunities for cooperative learning. After class, the entire English learning group will have to reflect on whether the group members describe each other's behavior, or how to adjust, give feedback, and reflect on this link to complete the English learning program more thoroughly and make the next Ocean English learning more frequent.

- Improve students' ability to use the Ocean English language in real life. The study of Ocean English is based on general considerations to promote the international development of Zhoushan. Therefore, students can learn to use Ocean English and combine Ocean English with life in order to better drive Zhoushan's external development. Under the premise of ensuring safety, the school can regularly organize students to go to the seaside and fishery to observe and study. Teachers can seize this opportunity to conduct field teaching. In addition, students' ability to improve their ability to use Ocean English in their daily life also requires the assistance of parents. Parents learn through Ocean English learning websites and acquire a certain level of Ocean English knowledge. Together with children, they communicate with their children in daily contact. Ocean English captures children's awareness and ability to learn English language.

\section{REFERENCES}

[1] 袁华明.浙江省获批设立自贸试验区[N].浙江日报，2016-09-01（0012）

[2] 舟山市人民政府. 浙江舟山群岛新区发展规划, 2013：3.

[3] 刘志维.群岛新区英语教学中海洋文化的导入及策略[J].浙江海洋学院学报(人文科学版),2016,33(03): 73-76

[4] 曲金良.海洋文化概论 [M], 中国海洋大学出版社, 2003.49

[5] 黄立,陈莹倩,赵佩格.海洋英语研究与推广一—上海海洋大学为例[J].语文学刊,2015(12):135-137.

[6] 林丽华.高校中外教师英语口语教学实证研究[J].武汉工程大学学报,2010,32(08):98-102.

[7] 王洋. 小初英语教学衔接策略研究[D].四川师范大学,2015.

[8] 张译尹. 小学生英语学习兴趣提升的行动研究[D].云南大学,2016.

[9] 汤于露. 小学英语翻转课堂的现状研究[D].山东师范大学,2016.

[10] 再保霞. 小组合作学习在小学英语教学中的应用研究[D].河北师范大学,2017.

Citation: Ye Qiongna \& Jiadai MAO. "Current Situation Analysis and Strategy Exploration of Ocean English Learning in Primary and Secondary Schools in Zhoushan". International Journal of Humanities Social Sciences and Education (IJHSSE), vol 5, no. 5, 2018, pp. 29-34doi: http://dx.doi.org/10.20431/2349. 0381.0505004 .

Copyright:@ 2018 Authors. This is an open-access article distributed under the terms of the Creative Commons Attribution License, which permits unrestricted use, distribution, and reproduction in any medium, provided the original author and source are credited. 